\title{
Against Epigraphy: Once More a Visit to Zen and History
}

T. H. BARRETT

Emeritus

SOAS, London

tb2@soas.ac.uk

Abstract: When in 1938 the pioneering Japanese Buddhist historian Ui Hakuju 宇井伯寿 extended his research to investigating the lineage of the eighth century Chan master Weiyan of Yaoshan 藥山 惟儼, he rejected the evidence contained in the master's epitaph by Tang Shen 唐伸, on the grounds that this inscription was probably a later forgery. Subsequent scholarship has generally come to the conclusion that the epitaph can only be genuine. Yet even as an indubitable historical document, it still needs to be read carefully with a view to the probable circumstances of its composition, as well as to possible problems in its transmission.

Keywords: Tang Shen, Ui Hakuju, Yaoshan Weiyan, Chinese Buddhist histories, Tang epigraphy

DOI: https://dx.doi.org/10.15239/hijbs.03.02.08 


\section{Ui Hakuju and Zen Studies}

The steady recovery of more and more early epigraphy from China has proved an immense boon to historians, and particularly to historians of religion, who have often had to depend in the past on transmitted sources that frequently describe events and personalities of one period through the lens of the preoccupations of one or more later periods in their transmission. The Chinese Chan tradition affords several examples of this. Scholars have therefore gladly looked beyond materials produced within the tradition itself to epigraphic records, even though in many cases such records do not survive to this day on stone and have themselves been transmitted through different stages of copying and recopying. If scrupulously handled, this evidence can, of course, be of great value. But it is still worth thinking about the circumstances that created such evidence before assessing what it might mean. The specific example examined to illustrate this point is an inscription composed by Tang Shen 唐伸 in the ninth century.

That students of Chan and Zen should have problems with the deployment of epigraphic materials should not in itself occasion any surprise. The systematic collection and study of epigraphy in China after all is generally traced back about a millennium, to the Song period, though there are some indications that it had become an adjunct to historical studies as early as the ninth century. ${ }^{1}$ It has more broadly been situated within the rise of archaeological studies in China. ${ }^{2}$ The critical study of Zen history, by contrast, is a product of a much more recent period, effectively no earlier than the opening decades of the twentieth century. The best known pioneer in this field, Nukariya Kaiten 忽滑谷快天 (1867-1934), does make use of the inscription by Tang Shen that is in question here, but in a positively eirenic fashion that gives no hint of past controversies, nor yet of their eventual revival in modern form. ${ }^{3}$ His remarks are in fact

1 For the general view, see e.g. Kuhn and Stahl, Annotated Bibliography to the Shike shiliao xinbian, 14. Note also Schafer, Mao Shan in T'ang Times, 38.

2 Vinsrygg, 'Time in Archaeological Thought: China and the West', 228. 
not without value, and will be addressed below once the considerable problems raised by Tang's evidence have been fully introduced.

As far as I am aware, despite the pre-war efforts by Japanese Buddhists in the field of Chinese epigraphic research as part of broader archaeological survey work, the detailed academic consideration of sources of the Chan tradition in conjunction with those derived from epigraphic records did not begin in earnest in the modern study of Zen until a little later, in the writings of Ui Hakuju 宇井伯寿 (1882-1963). Ui's formidable and exceptionally wide-ranging scholarship has so far resisted ready summary in English, while the only autobiographical note we have from his hand provides but a bare listing of his publications without comment. ${ }^{4}$ Rather than attempt any broader contextualisation of his work, therefore, the focus here is on how his initial efforts at deploying one or two epigraphical sources to supplement his general history of Chinese Chan have not always been endorsed by later scholars, followed by an assessment of the problems his work still raises today.

Ui's work on Chan history and epigraphy may be found in his second volume of Chan studies, published in 1939, a volume that also contains a number of primarily bibliographical essays on the Platform Sutra and other sources on Chan Buddhism of the Tang period. The fifth chapter, dated to March 1938 at the end, contains two biographical studies touching on longstanding epigraphic questions. ${ }^{5}$ The last sixteen pages treat the famous case of Daowu of Tianhuang Temple 天皇道悟 (748-807) and his alleged contemporary Daowu of Tianwang Temple 天王道悟, for both of whom epitaphs allegedly dating back to Tang times existed. The simultaneous existence of monks with the same name is not unexpected in China, where any number of such cases has plagued historians over the years. But in this case the issue was complicated by assertions over their spiritual lineages. In general those tracing their Chan transmis-

3 For this 1920 s pioneer (and on page 181 a reference to his sole predecessor, though that by a mere four years), see McRae, 'Glimmerings of India'.

4 Tsunoda, 'Ui Hakuju hakase jiden shōkai'.

5 Ui, Dai ni: Zenshūshi kenkyū, 425-72. 
sions back to the Sixth Patriarch-in other words, virtually every master of note by the end of the eighth century-divided into two main lines going back to two rather obscure disciples of the initially quite obscure Huineng 慧能 (638-713) himself. This division did not, however, prevent some from attempting to rewrite history by transferring some early figures from one line to the other in an effort to unify a common heritage to the benefit of their own position, or alternatively to block such moves. Such had been the sectarian origins of the two Daowus, over whose historicity debate had raged over the centuries in both China and Japan, with the seventeenth century witnessing a particular upsurge in polemics in China. ${ }^{6}$ The consensus of scholarship both pre-modern and modern is that while Tianhuang Daowu did exist, the second of these individuals, Tianwang Daowu, was a fictional character produced by inter-lineage rivalry in the late eleventh or early twelfth century and attested by a fake Tang inscription of that date. ${ }^{7}$ Though dissenting voices may still apparently be heard, in this specific case Ui's verdict may be said to have been entirely in line with the general trend. ${ }^{8}$

But in the other case, his conclusions, while equally not without a certain amount of precedent in pre-modern times, are somewhat different, and they have not stood the test of time so well. Even if during Ui's lifetime Japanese scholars do not seem to have contradicted him directly, this did not last, and by 1984 his arguments in the matter had been completely rejected, as they are by scholars within and beyond Japan today. ${ }^{9}$ In this instance he was dealing with

6 This phase is admirably summarized in Wu, Enlightenment in Dispute, 187-242, and for the longer-term background, 311-32.

7 A concise account of the main issues in the case may be found in Chen, Shishi yinian lu, 143-44, and in English, Jia, The Hongzhou School, 22-26.

$8 \mathrm{Wu}$, Enlightenment in Dispute, 391, note 42, notes that in this debate at least one Rinzai scholar still resists the conclusions of Nukariya and Ui.

9 Suzuki, Tò, Godai no Zenshū, 51-65, flatly contradicts Ui in some detail without mentioning him - though he does in note 71 on page 64 mention Nukariya. Jia, The Hongzhou School, 29, and note 50 on page 141, does cite Ui but follows more recent scholarship in rejecting his conclusions. Earlier Chen, 
a master named Weiyan of Yaoshan 藥山惟儼 (744-827), in Hunan, and once again with a lineage claim that ran count to accepted views within Chan sources as to who his teachers had been, according to a funerary inscription preserved originally in a secular source, attributed to the aforementioned writer of the Tang period, Tang Shen. Ui advances a number of arguments against the authenticity of this document, which differs from later sources not only in its description of his training as a Chan master but also as to some biographical details such as the date of his death. We should note at the outset that Ui did not make use of a very early Chan source that only became available after he wrote his piece, namely the Chodang chip or Zutang ji 祖堂 集, which offers much information from within the Chan tradition dating back to the mid-tenth century that was until the twentieth century only transmitted in Korea. ${ }^{10}$ With regard to Weiyan's biography at least, however, this work even if it provides early documentation for stories sometimes not attested until much later, does not offer any startling differences with other Buddhist texts already well known to scholarship in the early twentieth century. ${ }^{11}$

Shishi yinian lu, 148, adopts the same attitude as Ui but-perhaps inevitably within the compass of a concise reference work-without explaining his own reasons; Abe, Chügoku Zenshūshi kenkyū, 23, note 6, cites Ui, but somewhat non-committally; Yanagida, Zen goroku, 485, does not cite Ui but plainly agrees with him in his assessment of the epigraphy concerned.

10 On this work and its better-known successor in China, see Welter, 'Lineage and Context'.

11 The investigation of the historical value of this text was first undertaken in the post-war period by Yanagida Seizan, publishing initially under his original name of Yokoi 横井. See for the biographical details in the various early texts laid out comparatively by Suzuki, Tö, Godai no zenshū, 50-51, and for a full accounting of parallels in other materials the annotation provided in Sun, Kinugawa, and Nishiguchi, eds., Zutang ji, 223-39. 


\section{Ui’s Arguments Reconsidered}

Ui's criticisms of the authenticity of Tang Shen's piece are based on the version of the text that was to be found in the Quan Tang wen 全唐文, a massive thousand fascicle collection of all the literary prose compositions of the Tang period that had been put together in the early nineteenth century on the basis of source materials that were in Ui's day not always at all obvious-and indeed though a very useful index was published in Kyoto in 1960 indicating a very large number of its sources, including the earliest source of Tang Shen's work, which was evidently unknown to him, it still contains many important and apparently Tang period documents of quite obscure origin. ${ }^{12}$ Writing in $1938 \mathrm{Ui}$ was no doubt right to be cautious, especially in view of the doubts that had long been entertained about the two Daowus. But his critique of the origins of Tang's funerary inscription, 'Lizhou Yaoshan gu Weiyan dashi beiming, bing xu’澧州 藥山故惟藂大師碑銘并序 does itself require careful scrutiny. His first point, for example, is that Tang Shen-quite improbably improperly in his opinion-compares the Chan master more or less explicitly to Confucius in the beneficent effects of his teaching. But this tells us more about the late 1930s intellectual situation in Japan and the dominant attitude of respect for the sage than it does about the Tang dynasty, during which period the emperor had to intervene in 832 to stop disrespectful representations of Confucius appearing in a court entertainment. ${ }^{13}$ The Tang in general and Tang Shen in particular were probably much more relaxed about calling someone another Confucius than was Ui; by contrast in Song times a forger was perhaps rather less likely to write in such a way.

His next point, that Chongxu 冲虚, the disciple sent to the capital to commission a memorial inscription for his late master, is not

12 Hiraoka, Tödai no sanbun sakuin, 331, shows that Tang's item, no. 10709, was in the original 1814 Palace Edition of the Quan Tang wen at 536.2b, and in the Sibu congkan 四部叢刊 edition of the Tang wen cui (introduced below), 62.04a. The index is not concerned with cross-referencing Buddhist compendia.

13 Cefu yuangui 50.15a. 
known from any other source is true enough, but the significance of such obscurity need not derive from his being a fabrication of a forger, as we shall see. As for his suggestion that the metropolitan monastery, the Chongjing si 崇敬寺, that Chongxu went to in order to find an intermediary with connections to a literary figure, a monk who is described as the older brother of an aunt of Tang Shen's mother, Ui's assertion that this too was just a figment of a forger's imagination is just not true. It was certainly not the most illustrious religious institution in Chang'an, but though it had at one time during the early Tang been a nunnery, in its later existence it had apparently become a monastery once more. ${ }^{14}$ Yet Ui's fundamental objection is that no Tang Shen had ever existed in any case, and this assertion he says he derived from a seventeenth century discussion related to the 'two Daowus' controversy, specifically to a Japanese coda by Tokugan Yōson 德嚴養存 $(1632-1703)$ to a 1690 reprinting of a Chinese work, the Famen chugui 法門鋤宎 of $1667 .{ }^{15}$ Yōson was aware of Tang's piece, it turns out, not through wide reading in secular literature, but because it had been incorporated in a Buddhist historical chronicle completed in 1341, the Fozu lidai tongzai 佛祖 歴代通載 [Comprehensive Record of the Buddhas and Patriarchs Through the Ages] of Nianchang 念常 (1282-1341). ${ }^{16}$

Most of the points raised by Yōson against Tang Shen's piece are not very convincing, since Tang is mainly belaboured for not having

\footnotetext{
14 Tang buiyao 48, 990-91.

$15 \mathrm{Ui}$, Zenshüshi, 427. On the Famen chugui and its author, Weizhong Jingfu
} 位中浄符, see Wu, Enlightenment in Dispute, 227-28. The text of the work is available online from the Zoku Zōkyō edition $X$ no. 1604, vol. 86: 001, with the Goke benshō 五家辨正 of Yōson appended; his critique of Tang Shen’s inscription may be found in this edition on 0491b07-0492a12.

16 Here Tang's piece may be found in Nianchang, Fozu lidai tongzai 16, $T$ no. 49: 629a8-629c9. In fact Nianchang had incorporated this material into his own work from an earlier chronicle by Zuxiu 祖琇, Longxing Fojiao tonglun 隆興编年通論, 24, wherein Tang's piece is explicitly included because it brought into question the accepted account of Weiyan's lineage. On Zuxiu's work of 1163 or 1164, see Cao, Songdai Fojiao shiji yanjiu, 73-77. 
included in his inscription stories about Weiyan given in later Chan works, such as Weiyan's famous encounter with the Confucian scholar Li Ao 李朝 (772-836), the historicity of which is much more dubious than that of Tang's inscription. ${ }^{17}$ As for the allegation that he did not exist, that is nowadays, unlike the seventeenth century, very easily falsifiable, since Googling his name immediately gives the information that he was among those who passed a Tang examination, which means that he is independently recorded on the basis of Tang period secular records in the exhaustive study of such men carried out by the Qing scholar Xu Song 徐松 (1781-1848). ${ }^{18}$ Though other records of his achievements, apart from passing this one high level examination brilliantly and writing one inscription, are a complete blank, the former success was evidently well enough recognised that a slightly later graduate still remembered his outstanding ability a generation later. ${ }^{19}$ Unlike the second Daowu inscription, moreover, which only emerged at a time when debates over lineage were in full swing in Song dynasty Chan, Tang's piece was anthologised apparently for purely literary reasons as early as 1011, in a compendium of Tang prose put together by Yao Xuan 姚鉉 (968-1020), the Tang wencui 唐文粹 [Essence of Tang Prose]. ${ }^{20}$

But before turning to the questions of lineage that form the most striking and-to its Chinese Buddhist readers-most prob-

\footnotetext{
17 Cf. Barrett, Li Ao, 51-56.

18 Dengke ji kao 20, 722, for the year 825, and for his sources Jia, The Hongzhou School, 143, note 52.

19 Taiping guangji 181, 1347, which excerpts this evaluation from Zhao Lin 趙麟 (803-after 868), Yinbua lu 因話録, though the text of that work as transmitted separately mangles Tang's name. For Zhao, who graduated in 832 and wrote with detailed knowledge of the examinations, see Moore, Rituals of Recruitment in Tang China, 56-57, 89-90.

20 Tangwen cui, 62.4a-5b-the edition used appends collation notes, but not with regard to this piece. This anthology was the source of the Quan Tang wen version used by $\mathrm{Ui}$, and also of the version consulted in a Buddhist historical compendium by Yōson. On the significance of Yao's work for the authenticity of Tang's piece, see also Jia, The Hongzhou School, 28.
} 
lematic feature of Tang's composition, the less dramatic differences in biographical detail between it and the three Chinese Buddhist sources antedating Yao's anthology also need to be addressed, since a careful accounting of these differences by modern scholars has come to the conclusion that the compilers of all three of these texts were already familiar with Tang's work, even if they modified it in different ways. ${ }^{21}$ Apart from the Zutang ji, which has been placed as early as 952 but may be later in part, the other sources are Zanning 贊寧 (919-1001), Song Gaoseng zhuan 宋高僧傳 [Song Biographies of Eminent Monks], of 988, and Daoyuan 道原 (d.u.), Jingde cbuandeng lu 景德傳燈錄 [Jingde Record of the Transmission of the Lamp] of 1004 (revised by Yang Yi 楊億 [974-1020], 1011). Thus of these three, the first of these gives a date of 834 for Weiyan's death and an age of eighty-four sui; the second gives the date 828 and an age of seventy; the third gives the same as the first; Tang by contrast gives the date 827 and the age of eighty-four. While an age of seventy is hard to reconcile with other data on Weiyan's career, such as the sixty years as a fully ordained monk agreed by both Tang and the Jingde chuandeng $l u$, and 828 may be a miscalculation for 827 , the date of 834 would seem to be derived from the date of the creation of Tang's inscription, which has been muddled with the actual date of Weiyan's decease. Some problems remain: all four texts agree that Weiyan received full ordination in 773 , but this does not allow sixty years as a monk. It is also worth noting that Tang has Weiyan moving after an early peripatetic phase to his permanent base in Hunan at some point fairly soon after the mid-780s, yet speaks of him staying there for thirty years. These puzzles need to be borne in mind when examining Tang's assertions concerning Weiyan's Chan lineage.

21 The following analysis draws on Jia, The Hongzhou School, 29-31, and Suzuki, Tó, Godai no Zenshü, 50-54. The dependence of the three sources on Tang is clear from the collation notes provided in Sun, Kinugawa and Nishiguchi, ed., Zutang ji (see n. 11 above) and also in those given in Fan's edition, Song Gaoseng zhuan 17, 423-25 and 429. 


\section{Lineage Reconsidered}

First, however, it should be explained that the two lineages that later were perceived as constituting the sum of the Sixth Patriarch's spiritual legacy to posterity might best be regarded as not quite what later ages took them to be. By the time that the three early Buddhist sources were compiled, the two lineages had between them generated five distinct branches, and within those five branches or 'families' (wujia 五家) everyone seems to have had a very clear idea of their ancestry. But in the time of Weiyan and Tianhuang Daowu there is little sign that such was the case. The Sixth Patriarch was claimed as the teacher of their teacher's teachers, while other contemporaries looked back to other figures linking them back to the first patriarch to reach China from India, the renowned Bodhidharma. That it was the Sixth Patriarch rather than his better-known metropolitan contemporaries who had carried in his humble and obscure person the spiritual future of China was a notion that had been put about widely in the middle of the eighth century, but the idea had only risen to a truly dominant position in the second half of the century, thanks to the emergence of men who claimed his inheritance through one intermediate generation, and of one man in particular. This was Mazu Daoyi 馬祖道一 (709-788).

Mazu lived a provincial life, but not an obscure one like the Sixth Patriarch. ${ }^{22}$ The sayings attributed to him fill a book; the tally of his known disciples runs to well over a hundred names; he associated not just with local officials but with high level provincial governors, and in 791 shortly after his death he was commemorated by an inscription written by Quan Deyu 權德輿 (759-818), a well-known writer who was by this point already on his way to being employed by the central government in a policy post. ${ }^{23}$ The other lineage said to descend from the Sixth Patriarch via an intermediary disciple was represented at

22 As well as Jia, The Hongzhou School, it is possible to consult on Mazu in English a number of publications by Mario Poceski, notably Ordinary Mind.

23 The materials on Mazu's life are reviewed in Poceski, The Records of Mazu and the Making of Classical Chan Literature, with the inscription by Quan treated on pages $175-94$. 
this time by Shitou Xiqian 石頭希遷 (700-790), whose biography is much less conspicuous, even if he did contribute one ultimately very famous poem, the Cantong q $i$ 參同契, to the emergent Chan tradition. ${ }^{24}$ In the three texts of that tradition that have been introduced above as establishing Weiyan's place in it, Shitou is unambiguously designated his teacher, even if a number of encounters between Weiyan and Mazu were also passed down within the corpus of Chan sayings, on the basis of Weiyan's stay with Mazu for a period of three years, according to one source. ${ }^{25}$ By contrast, in Tang Shen's inscription attention is drawn to the good reputation in meditation studies during Weiyan's younger days of Shitou, Mazu, and also of an unknown master named Hong 洪 who lived on Mount Song 嵩山 in Henan, but only in the case of Mazu is Weiyan said to have sought him out, and to have stayed for fully twenty years, making it quite clear that in Tang's view he counted as a disciple. Recent scholarship, indeed, does not resist that conclusion, in view of the undeniable authenticity of Tang's work. ${ }^{26}$

Now of the two schools of Zen with an abiding strong institutional presence in Japan, the Sōtō school looks back to Weiyan as their link via Shitou to the Sixth Patriarch; the Rinzai school traces its origins to Mazu. Ui Hakuju was a priest of the former school. Historically, then, the doubts raised about Tang's inscription have always had strong sectarian overtones, and to some extent, perhaps, still continue to do so, even if the pattern of acceptance or rejection of its value in the twentieth century did not in fact divide along purely sectarian lines. ${ }^{27}$ Yet the status of Tang's piece as a genuine example of ninth

24 This work remains important within the tradition to this day: see Shunryu Suzuki, Branching Streams Flow in the Darkness, which contains (pages 20-23, and pages 190-91) both the Chinese text and two translations. For an account of Shitou and his legacy that is historically situated, see Robson, Power of Place, 281-97.

25 The material in question is translated by Mario Poceski, under the name of Cheng Chien Bikhshu, Sun Face Buddha, 81-82.

26 Jia, The Hongzhou School, 31.

27 Nukariya Kaiten (see below), was like Ui a member of the Sōtō school, 
century epigraphy is, in the light of all the evidence now available at this point, beyond doubt. One might quibble that the text could have suffered interpolation, since clearly we are dealing with epigraphic work that was transmitted solely in manuscript, rather than by any resort to rubbing, and there is no sign that a stone was known to any later writer that might confirm or deny the reference in it to twenty years with Mazu. Perhaps the outcome of Chongxu's efforts was destroyed in the mid-ninth century persecution of Buddhism; perhaps he never raised the funds to erect a memorial at all. This reading is, however, tacitly confirmed by our three early sources themselves, since all three of them plainly draw on Tang's writing, but conspicuously fail to mention the fact, though the endorsement of a monk's standing in the secular world provided by an inscription even if by a less than stellar literary figure is regularly mentioned in early Chan biography. Evidently the compilers of all three Chan works found its content problematic and preferred not to mention it.

\section{The Limits of Epigraphy}

But to say that this inscription is not a forgery does not absolve us from the need to interpret the information it contains as carefully as would be the case with any historical document. What follows here, then, is an effort at interpretation. Such an effort is by its very nature unlikely to be definitive, but it does suggest a possible way of resolving the confusions that have long surrounded Tang's composition. We know so little of Tang that it is impossible to discern what background knowledge of the emergent Chan tradition he brought to his task, though his degree result suggests that he was intelligent and widely read, at least in secular materials, and within his wider family circle there was evidently someone who had become a member of

and Suzuki Tetsuo was even teaching at the Sōtō university of Komazawa at the time that he reversed Ui's verdict; by contrast Yanagida Seizan, who in the 1970s at least accepted it (see note 9 above), was attached to the Rinzai university of Hanazono. 
the Buddhist clergy. We must assume, however, that his chief object was to cast in literary form the information conveyed to him by his informant, Chongxu. Of Chongxu, while he is clearly depicted as the leader of the group of Weiyan's adherents at the time of his death, we know precisely nothing. This strongly suggests that he was in fact a nonentity, which puts the whole content of the inscription in a perspective very different from that of, say, the inscription Quan Deyu composed for Mazu.

That inscription was produced within three years of Mazu's death. Such writings were not expected like today's newspaper obituaries to appear within weeks of their subject's passing, since commissioning was (we must assume, since our sources are not so vulgar as to reveal unbecoming details) bound to involve a certain amount of negotiation over such matters as fees. The much longer gap that intervened before Chongxu was able to secure an inscription from Tang suggests not simply that the former lacked the connections to enable him to locate a suitable literary talent but also perhaps that his monastic community took some time to raise the finances to embark on the task. The sum spent would no doubt have been a sound investment: a well written memorial would not simply have provided a focus for cultured lay visitors and encouraged more of them to extend their patronage to the community at Yaoshan but also through its wider circulation in manuscript would have raised Weiyan's home from relative provincial obscurity to wider notice. ${ }^{28}$ Weiyan died at a great age by the standards of the day, and perhaps during his later years his leadership had been less than ideally active, so there may well have been a decline in patronage that Chongxu needed to reverse.

Chongxu would of course have been concerned therefore to present as illustrious a career as possible for his teacher to the public, and though in a context that had strong ritual overtones it might have been unseemly or even considered spiritually dangerous to indulge

28 As Jia notes, The Hongzhou School, 30, and earlier Barrett, Li Ao, 52, note 80 , during his lifetime Weiyan had become the topic of a poem by a visiting junior official, but his group needed more publicity than that. 
in blatant falsehoods, the Buddhist concept of expedient means, whereby in the interests of higher truths some compromises on lesser matters were always possible, would have allowed him a certain amount of leeway. During the 820s there was a certain amount of activity promoting the claims of Shitou, but it had not made much progress, with the result that Chongxu would have been particularly concerned to stress instead any link with Mazu, whose disciples had dominated the Chan world of the early ninth century. ${ }^{29}$ Such might be one obvious explanation for the divergence between Chan tradition and Tang's inscription. Or alternatively, perhaps his master in old age had reminisced over his contacts with Mazu and now considered them of such retrospective significance that in his imagination they did stretch over two decades. Though Chongxu should have had an ordination certificate and records of Weiyan's relative seniority within the clergy to hand, for his master's Chan education he would have had to rely on an old man's memories. The senior students, whom the tradition remembers as part of the lineage whilst forgetting Chongxu himself, would in all likelihood have left the monastery years earlier to pursue their own careers as Chan teachers, and Chongxu himself quite possibly arrived too late to have met them, so corroboration may well have been very hard to come by in any case.

For Weiyan to have studied with Mazu as well as Shitou is at any rate intrinsically entirely unproblematic. Already in 1923, Nukariya Kaiten pointed out that despite the silence on the former connection in the earliest Chan sources, later compilations do in fact-while placing him in Shitou's lineage-make clear his strong links to Mazu; as Nukariya further observes, there are in fact several other examples of well-known contemporaries who likewise seem to have received instruction from both masters. ${ }^{30}$ The problem lies in the mention of

29 The incipient promotion of Shitou at this period is described by Poceski, Ordinary Mind, 98, but in his estimation it had not reached very far, with the true re-evaluation of his role taking place only in the second half of the ninth century.

30 Nukariya, Zengaku shisōshi, 479-81. For an example of a key text listing both men in connection with Weiyan, see Wudeng buiyuan 5, 247; for an exam- 
twenty years, which can only be suspected of being an exaggeration, whether deliberate or not. But as we have noted, all the chronological indications relating to Weiyan's early life in Tang's piece turn out to be problematic in any case, even when they should have been verifiable against documentary evidence. The only possible conclusion of the matter is that while Tang's inscription is authentic, all the numerical information given in it is, for whatever reason, unreliable in the state in which we now have the inscription, and may indeed have been inaccurate from the start. There is at least one example of a piece by a lay contemporary of his in which the independent survival of epigraphic evidence, which in fact comes from a memorial erected twenty years after the composition of the manuscript that was ancestral to the version included in the Tangwen cui, clearly indicates that Yao Xuan's work did include accidental errors of chronology. ${ }^{31}$ By contrast Tang's description of the administrative geography of Weiyan's situation seems entirely accurate, whereas all later Chan sources get it wrong. ${ }^{32}$

The exclusion of Shitou as a teacher-unless the implication is that Weiyan did visit both him and the long-forgotten Hong of Songshan-must even so be put down to other factors relating to Chongxu's need to emphasize the connections most advantageous to his situation and that of his monastic community at the time of Weiyan's death. In this regard every epigraphic piece must be treated as an occasional piece relating to conditions at a specific time which must be weighed up against other information derived from other sources not necessarily tied to the same circumstances. Tang makes no mention of Li Ao, or indeed of any visiting official. This suggests that in fact the entire story about the clash between the eminent

ple of another well-known figure with a similar dual heritage, see Sasaki, Iriya and Fraser, The Recorded Sayings of Layman P'ang, 45-48.

31 Cen, Tangren hangdi lu, 399. A thorough study by David McMullen of discrepancies between transmitted and epigraphically retrieved epitaphs (muzhi 墓誌) concludes that numbers were particularly susceptible to errors of transmission: cf. 'Boats Moored and Unmoored', 108-25.

32 Barrett, Li Ao, 52-53. 
Confucian and Weiyan found in Chan sources of the tenth century and thereafter is indeed a fiction, but as I have argued elsewhere it is a fiction that is consistent with the reputations of both men, thus at least endorsing the pictures of their characters given elsewhere. ${ }^{33}$ In many respects the rather conventional picture of Weiyan provided by Chongxu and summarized by Jinhua Jia certainly rings true. ${ }^{34}$ But the more heroic image passed down within the tradition does even so represent the impressions of him gathered by his best disciples when he was in his prime as a teacher, so who is to say which was the real Weiyan? It is at least possible that both versions of the man are in their way equally authentic.

Revisiting the issue of the epigraphic Weiyan versus the Weiyan of the 'Recorded Sayings' tradition is ultimately just another facet of the 'Zen and History' controversy, on which I have already reported elsewhere the thoughts of the great Zen scholar Yanagida Seizan 柳田聖山 (1922-2006). ${ }^{35}$ Though they were occasioned by my provision for him of a copy of an English language review of D. T. Suzuki that he had not had the opportunity to read, the case that I raised with him was not of course Suzuki but Li Ao and Weiyan, so given that context I make no excuse for repeating his response here. He reminded me that while we do not know as much as we might wish about the ninth century in China, we do know a great deal about Japan in the eighteenth century, and therefore about an obscure teacher of the immensely famous Hakuin Ekaku 白隠慧 鶴 (1686-1769), who in all that we may discover about him seems to have been no more than a very ordinary country priest. Yet in Hakuin's eyes he was clearly a figure of heroic stature. 'The truths of Zen are more akin to the truths of literature than to the truths of history' was his verdict. Plainly, the assaults on the value of transmitted epigraphy found in some Chan and Zen sources prepared to defend what they perceived as their own lineage against others hostile to the tradition represented by Shitou and Weiyan, and in their

\footnotetext{
33 Barrett, Li Ao, 57.

34 Jia, The Hongzhou School, 30.

35 Barrett, 'Arthur Waley'.
} 
defence determined to declare Tang Shen's work a forgery, show an animus against epigraphy that cannot be endorsed. Yet perhaps a certain sense of proportion concerning the use of epigraphy is still in order.

\section{Bibliography}

\section{Abbreviations}

Taishō shinshū daizōkyō大正新脩大蔵経. See Bibliography, Secondary Sources, Takakusu and Watanabe, eds.

\section{Primary Sources}

Cefu yuangui 册府元龜 [The 'Primal Turtle' of Documentary Archives]. 1000 juan. By Wang Qinruo 王欽若 (962-1025), et al., 1013. Beijing: Zhonghua shuju 中華書局, 1960.

Dengke ji kao 登科記考 [Investigation of the Record of Examination Successes]. 30 juan. By Xu Song 徐松 (1781-1848). Beijing: Zhonghua shuju 中華書局, 1984.

Fozu lidai tongzai 佛祖歴代通載 [Comprehensive Record of the Buddhas and Patriarchs Through the Ages]. 22 juan. By

Nianchang 念常 (1282-?), 1341. T. no. 2036, vol. 49.

Song Gaoseng zhuan 宋高僧傳 [Biographies of Eminent Monks Compiled in the Song]. 30 juan. By Zanning 贊寧 (919-1001), 988. Reference made to Fan Xiangyong 范祥雍 edition. Beijing: Zhonghua shuju 中華書局, 1987.

Taiping guangji 太平廣記 [Broad Record of the Taiping Period]. 500 juan. By Li Fang 李昉 (925-996), et al., 978. Beijing: Zhonghua shuju 中華書局, 1959.

Tang buiyao 唐會要 [Collected Tang Essentials]. 100 juan. By Wang $\mathrm{Pu}$ 王溥 (922-982), 961. Shanghai: Shanghai guji chubanshe 上海古籍出版社, 1991.

Tang wencui 唐文粹 [Finest of Tang Prose]. 100 juan. By Yao Xuan 姚鉉 (968-1020), 1011. Reference to Taipei: Shijie shuju 世界書 局, 1972, reprint of 1893 Hangzhou edition. 
Wudeng buiyuan 五燈會元 [Compilation of Five Histories of Chan]. 20 juan. By Puji 普濟 (1179-1253), 1253. Reference made to edition of Su Yuanlei 蘇淵雷, Beijing: Zhonghua shuju 中華書局, 1984.

Zutang ji 祖堂集 [Collection of the Patriarchs' Hall]. 20 juan. By Jing 静 and Yun 筠, 953. Reference made to Sun Changwu 孫昌 武, Kinugawa Kenji 衣川賢次 and Nishiguchi Yoshio 西口芳男, eds. Beijing: Zhonghua shuju 中華書局, 2007.

\section{Secondary Sources}

Abe Chōichi 阿部肇一. Chūgoku Zenshūshikenkyū 中国禅宗史研究 [Research in the History of the Chinese Chan School]. Tokyo: Shōshin shobō 誠信書房, 1963.

Barrett, T. H. 'Arthur Waley, D. T. Suzuki and Hu Shih: New Light on the "Zen and History" Controversy'. Buddhist Studies Review 6, no. 2 (1989): 116-21.

L Li Ao: Buddhist, Taoist, or Neo-Confucian? Oxford: Oxford University Press, 1992.

Cao Ganghua 曹剛華. Songdai Fojiao shiji yanjiu 宋代佛教史籍研 究 [Research into Song Period Buddhist Historical Writings]. Shanghai: Huadong shifan daxue chubanshe 華東師範大學出版 社, 2006.

Cen Zhongmian岑仲勉. Tangren hangdi lu 唐人行第録 [Record of Tang Persons Age Rankings]. Beijing: Zhonghua shuju 中華書局, 1962.

Chen Yuan 陳垣. Shishi yinian lu 釋氏疑年録 [Record of Doubtful Dates for Buddhists]. Beijing: Zhonghua shuju 中華書局, 1964.

Cheng Chien Bikhshu [Mario Poceski]. Sun Face Buddha: The Teachings of Ma-tsu and the Hung-chou School of Ch'an. Berkeley: Asian Humanities Press, 1992.

Hiraoka Takeo 平岡武夫, ed. Tódai no sanbun sakuin 唐代の散文索 引 [Index to Tang Prose]. Kyoto: Dōhōsha 同朋舎, 1977 reprint of 1960 .

Jia, Jinhua. The Hongzhou School of Chan Buddhism in Eighth through Tenth-century China. Albany: State University of New York Press, 2006. 
Kuhn, Dieter, and Helga Stahl. Annotated Bibliography to the Shike shiliao xinbian 石刻史料新編 [New Edition of Historical Materials Carved on Stone]. Heidelberg: edition forum, 1991.

McMullen, David. 'Boats Moored and Unmoored; Reflections on the Dunhuang Manuscripts of Gao Shi's Verse'. Harvard Journal of Asiatic Studies 73, no. 1 (June 2013): 83-145.

McRae, John R. 'Glimmerings of India: Nukariya Kaiten 忽滑谷 快天 and the Transmission of Zen from India to China'. In Buddhist Transformations and Interactions: Essays in Honor of Antonino Forte, edited by Victor H. Mair, 179-234. Amherst: Cambria Press, 2017.

Moore, Olive. Rituals of Recruitment in Tang China: Reading an Annual Register in the Collected Statements by Wang Dingbao (870-940). Leiden: Brill, 2004.

Nukariya Kaiten 忽滑谷快天. Zengaku shisōshi 禅学思想史 [An Intellectual History of Zen Studies]. Tokyo: Genkōsha 玄黄社, 1923.

Poceski, Mario. Ordinary Mind as the Way: The Hongzhou School and the Growth of Chan Buddhism. New York: Oxford University Press, 2007.

- The Records of Mazu and the Making of Classical Chan Literature. New York: Oxford University Press, 2015.

Robson, James. Power of Place: The Religious Landscape of the Southern Sacred Peak (Nanyue 南获) in Medieval China. Cambridge: Harvard University Press, 2009.

Sasaki, Ruth Fuller, Iriya Yoshitaka, and Dana R. Fraser. The Recorded Sayings of Layman P'ang, A Ninth-Century Zen Classic. New York and Tokyo: Weatherhill, 1971.

Schafer, Edward H. Mao Shan in T'ang Times. Boulder: Society for the Study of Chinese Religions, 1980.

Suzuki, Shunryu. Branching Streams Flow in the Darkness: Zen Talks on the Sandokai. Berkeley: University of California Press, 1999.

Suzuki Tetsuo 鈴木哲雄. Tö, Godai no Zenshū 唐、五代の禅宗 [The Chan School of the Tang and Five Dynasties]. Tokyo: Daitō shuppansha 大東出版社, 1984.

Takakusu Junjirō 高楠順次郎, and Watanabe Kaigyoku 渡邊海旭, eds. Taishō shinshū daizōkyō 大正新修大藏經 [Buddhist Canon 
Compiled during the Taishō Era (1912-1926)]. 100 vols. Tokyo:

Taishō issaikyō kankōkai 大正一切經刊行會, 1924-1932.

Tsunoda Haruo 角田春雄. 'Ui Hakuju hakase jiden shōkai' 宇井

伯寿博士自伝紹介 [An Introduction to the Autobiography of

Dr. Ui Hakuju]. Indogaku Bukkyōgaku kenkyū 印度学仏教学

研究 [Research in Indology and Buddhology] 16, no. 2 (1968):

886-90.

Ui Hakuju 宇井伯壽. Dai ni: Zenshūshi kenkyū 第二禅宗史研

究 [Second Volume of Research into the History of the Zen

School]. Tokyo: Iwanami shoten 岩波書店, 1939.

Vinsrygg, Synnøve. 'Time in Archaeological Thought: China and the

West'. In Time, Science, and Society in China and the West, edited

by J. T. Fraser, N. Lawrence, and F. C. Haber, 225-40. Amherst:

The University of Massachusetts Press, 1986.

Welter, Albert. 'Lineage and Context in the Patriarch's Hall

Collection and the Transmission of the Lamp'. In The Zen

Canon, edited by Steve Heine and Dale S. Wright, 158-79. New

York: Oxford University Press, 2004.

Wu, Jiang. Enlightenment in Dispute: The Reinvention of Chan

Buddhism in Seventeenth-Century China. New York: Oxford

University Press, 2008.

Yanagida Seizan 柳田聖山. Zen goroku 禅語録 [Chan Recorded

Sayings]. Tokyo: Chuokoronsha 中央公論社, 1974. 